University of Nebraska - Lincoln

DigitalCommons@University of Nebraska - Lincoln

Agronomy \& Horticulture -- Faculty Publications

Agronomy and Horticulture Department

1990

\title{
Evaluation of Seeding Rates of AU Triumph and Endophyte- Infected Kentucky 31 Tall Fescue
}

Jeffrey F. Pedersen

University of Nebraska-Lincoln, jpedersen1@unl.edu

D. M. Ball

Auburn University

Follow this and additional works at: https://digitalcommons.unl.edu/agronomyfacpub

Part of the Agricultural Science Commons, Agriculture Commons, Agronomy and Crop Sciences Commons, Botany Commons, Horticulture Commons, Other Plant Sciences Commons, and the Plant Biology Commons

Pedersen, Jeffrey F. and Ball, D. M., "Evaluation of Seeding Rates of AU Triumph and Endophyte-Infected Kentucky 31 Tall Fescue" (1990). Agronomy \& Horticulture -- Faculty Publications. 951.

https://digitalcommons.unl.edu/agronomyfacpub/951

This Article is brought to you for free and open access by the Agronomy and Horticulture Department at DigitalCommons@University of Nebraska - Lincoln. It has been accepted for inclusion in Agronomy \& Horticulture -Faculty Publications by an authorized administrator of DigitalCommons@University of Nebraska - Lincoln. 


\title{
Evaluation of Seeding Rates of AU Triumph and Endophyte-Infected Kentucky 31 Tall Fescue
}

\author{
J. F. Pedersen* and D. M. Ball
}

Increased difficulty in stand establishment of tall fescue (Festuca arundinacea Schreb.) has been reported by producers since the introduction of endophyte (Acremonium coenophialum Morgan-Jones and Gams)-free tall fescue seed into the market place. This has encouraged the use of higher seeding rates for endophyte-free tall fescue without scientific basis. The objective of this study was to determine whether 'AU Triumph', and endophyte-free cultivar, and endophyte-infected 'Kentucky 31' differ in minimum seeding rates for successful establishment. Experiments were established at two locations in each of two years, using a randomized complete block with four replications. Soils at the two locations were Cahaba fine sandy loam (fine-loamy, siliceous, thermic Typic Hapludult) and Sumter clay (fine-silty, carbonatic, thermic Rendollic Eutrochreps). For a period of 17-19 mo after planting, dry matter yields were determined whenever forage reached approximately 6 in. in height. Each location $\times$ year combination was analyzed independently. Linear and quadratic effects of seeding rate were tested at each harvest date, and single degree of freedom comparisons were made for cultivar effects and their interactions with the linear and quadratic effects. At harvest dates when significant linear or quadratic effects were detected for seeding rate, response curves were fitted. In some juvenile stands (first or second post planting harvests), dry matter yields increased with increasing seeding rates, or increased with increasing seeding rates to approximately $20 \mathrm{lb}$ seed/acre and then leveled off. Seeding rates did not affect tall fescue yields at later harvests. Lack of cultivar interactions with seeding rate indicates there is no basis for recommending higher seeding rates of $\mathrm{AU}$ Triumph than for endophyte-infected Kentucky 31 under these conditions.

$\mathrm{T}^{\mathrm{s}}$ HE COMMERCIAL availability of endophyte-free tall fescue has created new management concerns. One of the most pressing of these relates to stand establishment. Traditional recommended seeding rates for pure stands of tall fescue for forage range from 10 to 25 lb/acre (Buckner, 1985; Taylor et al., 1979). Recent evidence has shown that endophyte-free tall fescue cultivars or lines have lower germination rates and percentages in the laboratory than the same cultivars or lines with endophyte infection (Clay, 1987; Rice and Pinkerton, 1987). They also have smaller establishment-year yields in the field (Pedersen and Joost, 1989). Although this evidence is recent, producers have reported increased difficulty in stand establishment of endophyte-free tall fescue since its introduction. Consequently, some have used high seeding rates for endophyte-free tall fescue in

J.F. Pedersen, USDA-ARS Wheat, Sorghum, and Forage Research Unit, Agronomy Dep., Univ. of Nebraska, Lincoln, NE 68583. D.M. Ball, Agronomy and Soils Dep., Auburn University, AL 36849. Contribution of the Alabama Agric. Exp. Stn. Received May 1989. *Corresponding author.

Published in J. Prod. Agric. 3:109-111 (1990). an attempt to compensate for the perceived increased difficulty in stand establishment. The objective of this study was to determine whether 'AU Triumph', an endophyte-free cultivar (Pedersen et al., 1983), and endophyte-infeced 'Kentucky 31' differ in minimum seeding rate for successful establishment, using subsequentyear dry matter yield as the criterion.

\section{MATERIALS AND METHODS}

AU Triumph ( $0 \%$ endophyte-infected) and Kentucky 31 ( $90 \%$ endophyte-infected) were seeded at 5, 10, 20, 30,40 , and $50 \mathrm{lb} /$ acre in well-prepared seedbeds at each of two locations in each of $2 \mathrm{yr}$. Seeding dates were 1 Oct. 1983 and 4 Oct. 1984 at the Auburn University Plant Breeding Unit, Tallassee, AL, and 15 Oct. 1983 and 10 Oct. 1984 at the Auburn University Black Belt Substation, Marion Junction, AL. Soils at the two locations were Cahaba fine sandy loam and Sumter clay, respectively. Plots were $5 \mathrm{ft}$ by $20 \mathrm{ft}$ and were fertilized to $22 \mathrm{lb} /$ acre $P$ and $100 \mathrm{lb} / a c r e ~ K$ at Tallassee, and $32 \mathrm{lb} /$ acre $P$ and $158 \mathrm{lb} /$ acre $K$ at Marion Junction. Nitrogen was applied at $60 \mathrm{lb} /$ acre prior to seeding, and again at that rate each Sept. and Mar. at both locations for the duration of the study. Seeds were planted approximately 0.25 to 0.5 in. deep. In 1983, seed was planted with calibrated Planet Jr.'s ${ }^{1}$ (Power Mfg., P.O. Box 707, Bennettsville, SC 29512) in 6 in. rows to simulate drilling, and in 1984, seed was planted with a small plot drill in 7 in. rows. Broadleaf weeds were controlled with broadcast application of 2,4-D amine [(2,4-dichlorophenoxy) acetic acid] at $0.5 \mathrm{lb}$ a.i./acre as needed.

When at least 6 in. of growth had accumulated, a 30 in. by $20 \mathrm{ft}$ section was removed from the center of each plot with a flail harvester to a height of 3 in., then weighed. Subsamples from each plot were dried at $150^{\circ} \mathrm{F}$ to determine dry matter content and total dry matter yield.

The design was a randomized complete block with four replications at each location and in each year. Each location $\times$ year combination was analyzed independently using the General Linear Models procedure of SAS (SAS Inst. Inc., 1985). Linear and quadratic effect of seeding rate were tested at each harvest date, and single degree of freedom comparisons were made for cultivar effects and their interactions with the linear and quadratic effects. At harvest dates when significant $(P \leq 0.05)$ linear or quadratic effects were detected for seeding rate, response curves were fitted.

\footnotetext{
${ }^{1}$ Names of products are included for the benefit of the reader and do not imply endorsement of preferential treatment by Auburn University of the Alabama Agricultural Experiment Station.
} 
Table 1. Significance of cultivar and rate of seeding effects in a 2-yr two-location study comparing AU Triumph and Acremonium coenophialum-infected Kentucky 31 tall fescue.

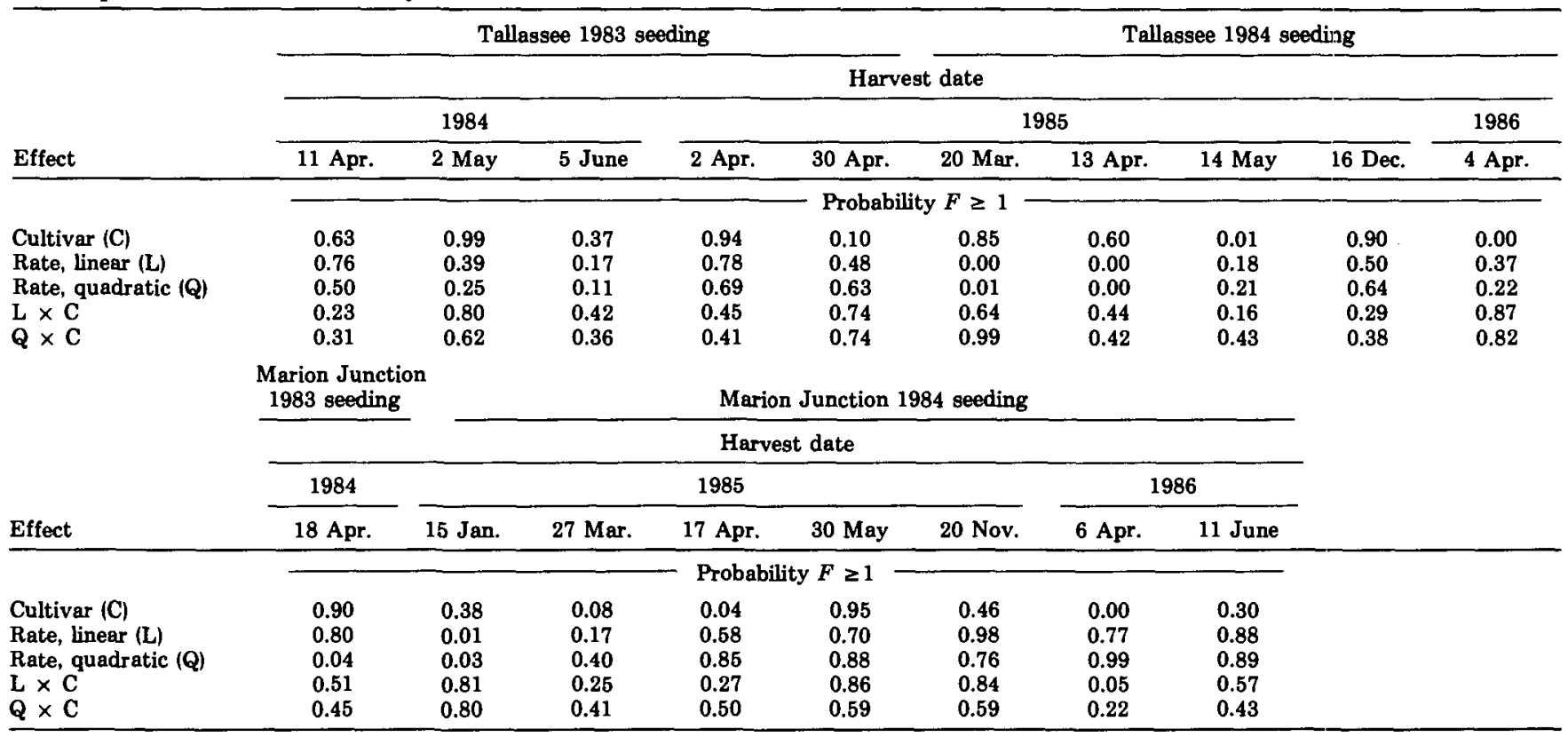

Table 2. Mean yields by cultivar in a 2-yr, two-location study comparing AU Triumph and Acremonium coenophialum-infected Kentucky 31 tall fescue.

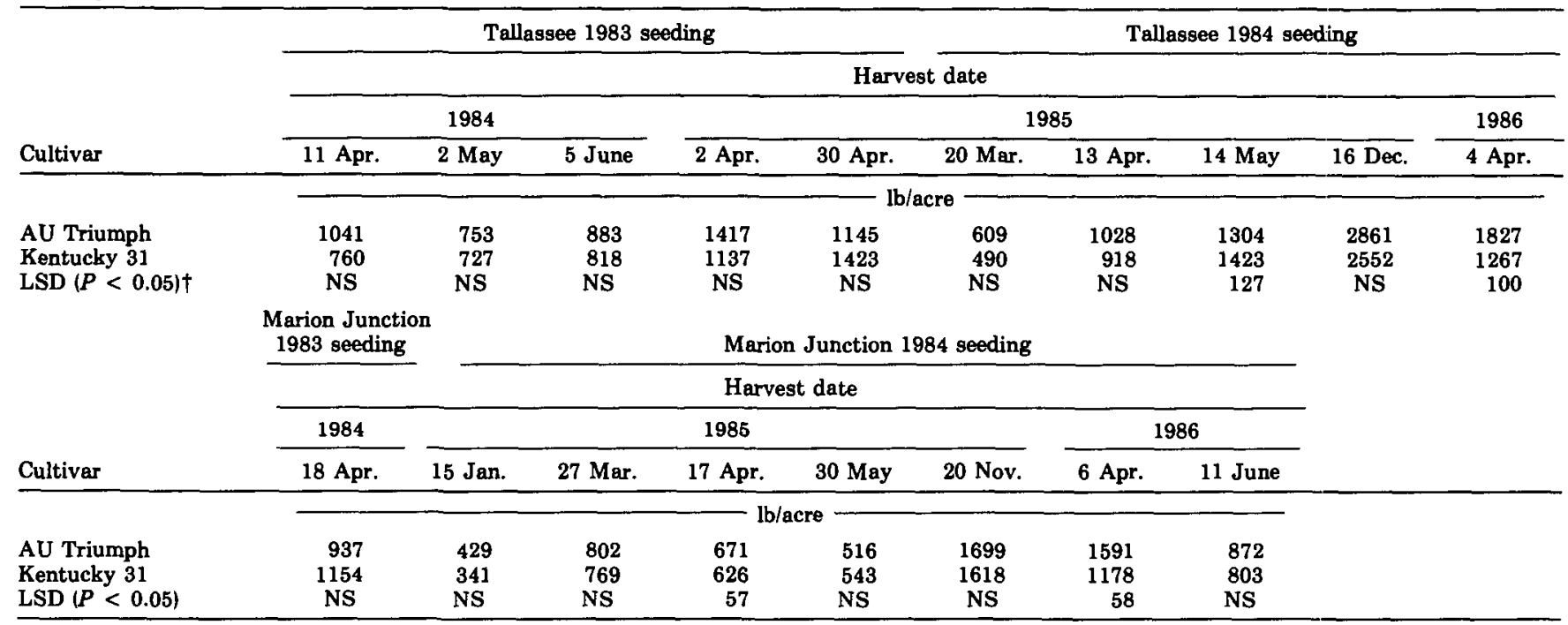

$\dagger \mathrm{F}$ test protected LSD.

\section{RESULTS AND DISCUSSION}

At Tallassee, no rate effects were significant for the duration of the test seeded in 1983 (Table 1). In the experiment seeded in 1984, both linear and quadratic seeding rate effects were significant for the first two harvest dates, but were not significant thereafter. At Marion Junction, quadratic rate effects were significant for the first harvest of the test seeded in 1983. This experiment was lost due to drought, and no further harvests were possible. In the experiment seeded in 1984, both linear and quadratic seeding rate effects were significant for the first harvest date, but again were not significant thereafter. Seeding rate interactions with cultivar were not significant at any date or location, with the exception of a single linear seeding rate $\times$ cultivar interaction at Marion Junction 16 mo after the 1984 experiment was established.
Since seeding rates ranging from 5 to $50 \mathrm{lb} /$ acre did not affect tall fescue yields after the first or second harvest, it does not appear that seeding rate per se is of critical long term importance in tall fescue pasture establishment in well prepared seedbeds. The lack of cultivar interactions with seeding rate indicates that there is no basis for recommending higher seeding rates of $\mathrm{AU}$ Triumph than for endophyte-infected Kentucky 31 under these conditions. In the one instance where a seeding rate $x$ cultivar interaction was significant, the stands were mature and AU Triumph yielded more than endophyteinfected Kentucky 31 (Table 2).

Response curves for dry matter yield with increasing seeding rate are shown for the locations $x$ harvest dates where rate effects were significant (Fig. 1). In some juvenile stands (first or second post planting harvests) dry matter yields increased with increasing seeding rates, or 
Marion Junction 1983 Seeding

18 Apr 1984 Harvest

Yield (ib/acre)
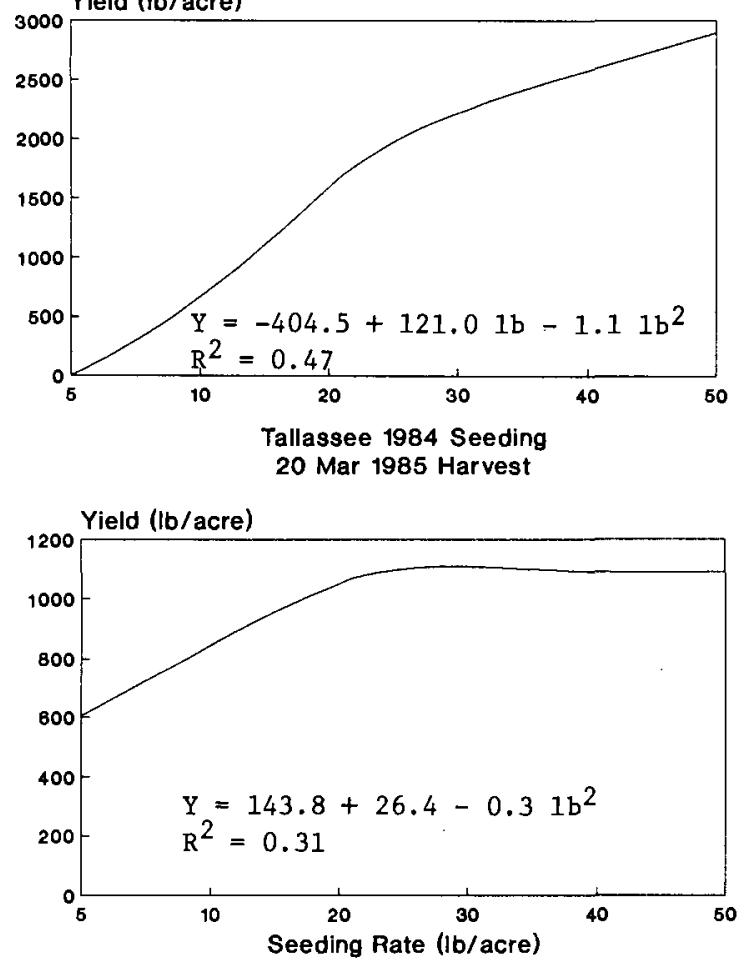

Marion Junction 1984 Seeding

15 Jan 1985 Harvest
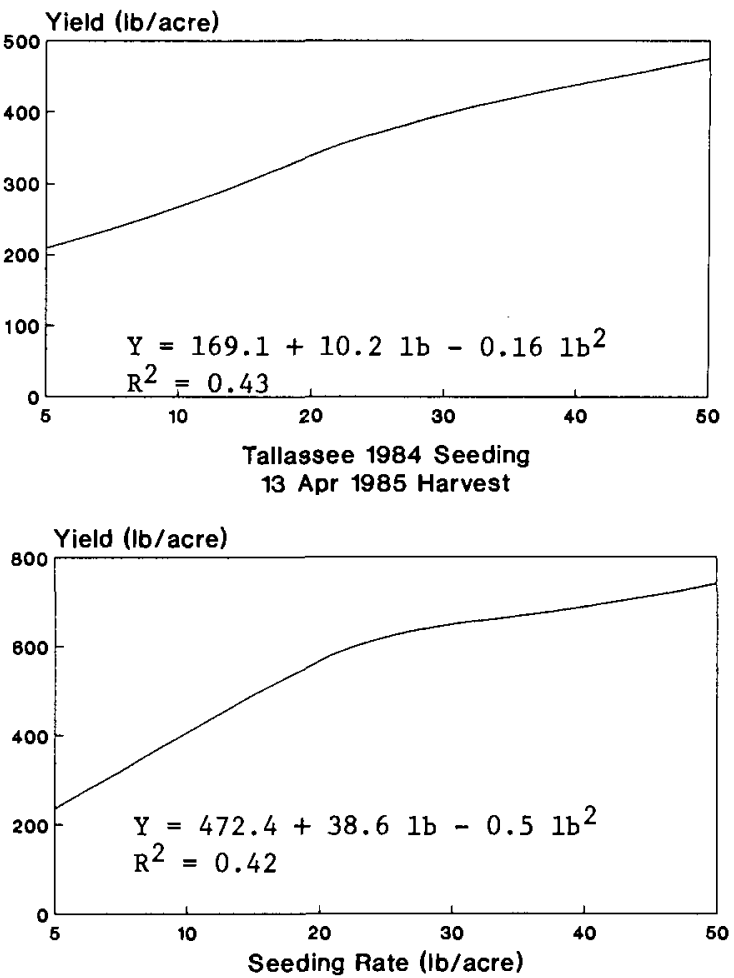

Fig. 1. Response curves for juvenile dry matter yield with increasing seeding rate.

increased with increasing seeding rates to approximately $20 \mathrm{lb}$ seed/acre and then leveled off. Seeding rates did not affect tall fescue yields at later harvests.

Cultivar effects were rarely significant (Table 1). Significant differences that did occur usually could be explained by the earlier seasonal yield distribution of $\mathrm{AU}$ Triumph than that of Kentucky 31 (Pedersen et al., 1983). Mean cultivar yields are shown for each location $\times$ date (Table 2).

Since these studies showed that normal seeding rates used for endophyte-infected Kentucky 31 were adequate for AU Triumph, why are producers reporting difficulty in establishing AU Triumph and other endophyte-free cultivars? It is possible that under environmental conditions not encountered in the tests reported in this paper, endophyte-free plants are less able to survive than endophyte-infected plants. For example, it has been reported that endophyte-free tall fescue plants are less drought tolerant than endophyte-infected plants (Arachevaleta et al., 1989).

More probably, producers are recognizing a slower rate of stand establishment in endophyte-free cultivars. Clay (1987) showed decreased seedling tiller number and dry matter accumulation in endophyte-free Kentucky 31 than in endophyte-infected Kentucky 31 in a growth chamber at 10 and 14 wk of age. Pedersen and Joost (1989) showed lesser dry matter yields in the field at $13 \mathrm{wk}$ of age in two endophyte-free tall fescue lines than with the same lines infected with endophye. In our experiments, high seeding rates were associated with high yields at the earliest harvest dates. However, no seeding rate $\times$ cultivar interactions were significant at the early harvest dates.
Thus, despite reported relationships between reduced seedling growth rate and endophyte infection in tall fescue, it does not appear that increasing seeding rate of AU Triumph above that of Kentucky 31 is necessary for successful establishment. Unless additional studies demonstrate that higher seeding rates are needed, changes in seeding rate recommendations for AU Triumph under good seedbed conditions cannot be justified.

\section{REFERENCES}

Arachevaleta, M., C.W. Bacon, C.S. Hoveland, and D.E. Radcliffe. 1989. Effect of tall fescue endophyte on plant response to environmental stress. Agron. J. 81:83-90.

Buckner, R.C. 1985. The fescues. p. 233-240. In M.C. Heath et al. (ed.) Forages, the science of grassland agriculture. 4th ed. Iowa State University Press, Ames.

Clay, K. 1987. Effects of fungal endophytes on the seed and seedling biology of Lolium perenne and Festuca arundinacea. Oecologia 73:358-362.

Pedersen, J.F., R.L. Haaland, C.S. Hoveland, C.D. Berry, S.P. Schmidt, and R.R. Harris. 1983. Registration of AU Triumph tall fescue. Crop Sci. 23:182.

Pedersen, J.F., and R.L. Joost. 1989. Effect of Acremonium coenophialum on seedling vigor and persistence of lines of tall fescue. p. 31-312. In Proc. XVI Int. Grassl. Congress, Nice, France, 4-11 Nov. French Grassl. Soc.

Rice, J.S., and B.W. Pinkerton. 1987. Effect of endophyte on germination of tall fescue under conditions of temperature and water stress. p. 11. In Abstrasts South. Assoc. Agric. Scientists, Agron. Div. South. Branch ASA.

SAS Institute. 1985. SAS/STAT ${ }^{\mathrm{TM}}$ Guide for personal computers. 6th ed. SAS Institute, Cary, NC.

Taylor, T.H., W.F. Wedin, and W.C. Templeton, Jr. 1979. Stand establishment and renovation of old sods for forage. In R.C. Buckner and L.P. Bush (ed.) Tall fescue. Agronomy 20:155-170. 